Dariusz Jarosz

Maria Pasztor

Warszawa

\title{
Rola sporu o Bibliotekę Polską w Paryżu w stosunkach polsko-francuskich w latach 1945-1980
}

Dzieje Biblioteki Polskiej w Paryżu, zwłaszcza te najnowsze, rzadko były przedmiotem bardziej wyczerpujących studiów naukowych. Zwykle analizowano jej rolę jako ważniej emigracyjnej instytucji kulturalnej i ośrodek kształtowania niepodległej myśli politycznej ${ }^{1}$. Tymczasem po II wojnie światowej stała się ona przedmiotem istotnego sporu w stosunkach kulturalnych między Polską a Francją.

Biblioteka została założona w 1838 r. staraniem kół emigracyjnych. W 1903 r. przyłączono do niej Muzeum Mickiewiczowskie. Ta zasłużona placówka, którą w 1891 r. Polskie Towarzystwo Historyczno-Literackie scedowało krakowskiej Polskiej Akademii Umiejętności (PAU), wznowiła działalność 29 listopada 1944 r. ${ }^{2}$ W tym dniu jej dyrektor Franciszek Pułaski na pierwszym powojennym zebraniu złożył „Sprawozdanie o losach Biblioteki Polskiej i Muzeum Mickiewiczowskiego". Stopniowo powracały depozyty złożone w południowej Francji, jak i książki zabrane przez Niemców (te ostatnie w lipcu 1947 roku). Status prawny tej instytucji skomplikował się $z$ chwilą, gdy 13 czerwca 1945 r., a więc tuż przed powołaniem w Polsce zdominowanego przez komunistów Tymczasowego Rządu Jedności Narodowej i jego uznaniem przez Francję - Pułaski podpisał (przy poparciu udzielonym przez konsulat generalny w Paryżu, obsadzony wówczas jeszcze przez przedstawicieli rządu emigracyjnego) $z$ paryskim przedstawicielem Zjednoczenia Polskiego Rzymsko-Katolickiego w Ameryce $z$ siedziba w Chicago ks. Augustynem Jakubisiakiem akt notarialny „wydzierżawienia” Biblioteki tejże organizacji na okres osiemnastu lat. Posunięcie to bez wątpienia miało charakter polityczny; chodziło o zachowanie emigracyjnych tradycji i skomplikowanie procesu przejmowania placówki przez władze warszawskie. O fakcie tym Zarząd PAU dowiedzial się dopiero w lutym 1946 r. W celu wyjaśnienia zaistniałej sytuacji 8 marca 1946 r. przybył do Paryża jako delegat Aka-

\footnotetext{
${ }^{1}$ Zob. m.in. I. Gałęzowska, Bibliothèque Polonaise de Paris 1839-1939, Paris 1946; F. Pułaski, Biblioteka Polska w Paryżu w latach 1893-1948, Paryż 1948; A. Mężýnki, Biblioteka Polska w Paryżu. Rys historyczny, zbiory, dzień dzisiejszy, w: „Przegląd Biblioteczny” 1983, z. 1, s. 13-25.

${ }^{2}$ Biblioteki polskie poza krajem w latach 1938-1948. Informator, red. B. Bieńkowska, Poznań 2005,
} s. 153-154. 
demii prof. Stanisław Wędkiewicz. Efektem jego misji było oficjalne oddzielenie Stacji Naukowej PAU w Paryżu od Biblioteki Polskiej PAU, co nastapiło 18 czerwca $1946 \mathrm{r}^{3}$

Uznanie przez powojenną Francję władz Polski Ludowej i nawiązanie $z$ nimi stosunków dyplomatycznych znacznie komplikowało sytuację Biblioteki. Ten problem stał się przedmiotem istotnej kontrowersji między Warszawą i Paryżem już przy okazji prowadzonych rozmów dyplomatycznych w związku $z$ planami podpisania dwustronnej konwencji kulturalnej. Strona polska argumentowała, iż przekazanie jej kontroli nad Biblioteką winno być formą rewanżu za zgodę na rozwój aktywności Instytutu Francuskiego w Polsce ${ }^{4}$.

Mimo tych trudności udało się wynegocjować i podpisać 19 lutego $1947 \mathrm{r}$. tekst kompromisowy konwencji „dotyczącej współpracy intelektualnej” (Polska ratyfikowała ją 11 czerwca 1947 r. $)^{5}$. W art. 5 tego dokumentu zapowiadano, iz dla realizacji nakreślonych wspólnie celów zostanie powołana „możliwie najrychlej” Komisja Mieszana Polsko-Francuska, złożona $z$ dwóch podkomisji, $z$ siedzibami w Warszawie i Paryżu. Na czele każdej $z$ nich miał stać minister oświaty lub jego pełnomocnik, po dwóch delegatów każdego $z$ zainteresowanych ministerstw i dwóch przedstawicieli ambasady drugiej układającej się strony. Ich członkowie byli mianowani na okres trzyletni (art. 6). Komisja Mieszana zobowiązana została do tego, aby możliwie najszybciej opracować propozycje konieczne dla zawarcia układów na temat wznowienia Instytutu Francuskiego w Warszawie, Krakowie i Poznaniu „wraz z jego ewentualnymi oddziałami” oraz funkcjonowania Biblioteki Polskiej i Stacji Naukowej w Paryżu, należących do Polskiej Akademii Umiejętności, równie $\dot{z}, z$ ich ewentualnymi oddziałami” (art. 7a).

Dla podkreślenia znaczenia ratyfikacji tego aktu do Polski przyjechał w tym czasie (maj-czerwiec 1947 r.) Louis Joxe, stojący na czele Dyrekcji do Spraw Kulturalnych we francuskim MSZ. W jego obecności nastapiła oficjalna inauguracja Instytutu Francuskiego w tymczasowej siedzibie w Warszawie i w Krakowie oraz wymiana dokumentów ratyfikacyjnych ${ }^{6}$.

\footnotetext{
${ }^{3}$ W. Rolbiecki, Polska Stacja Naukowa w Paryżu w latach 1893-1978, w: D. Rederowa, B. Jaczewski, W. Rolbiecki, Polska Stacja Naukowa w Paryżu w latach 1893-1978, Ossolineum 1982, s. 212-230; D. Rederowa, Formy wspótpracy Polskiej Akademii Umiejętności z zagranica (1873-1952), „Studia i Materiały z Dziejów Nauki Polskiej” 1966, z. 10, seria A, s. 126-127.

${ }^{4}$ Archives du Ministère des Affaires étrangeres (dalej: AMAE), Direction de la Direction generale des Relations culturelles, scientifiques et techniques, Enseignement 1945-1961, Pologne 1945-1947, sygn. 77, M. R. Garreau ambassadeur en Pologne a G. Bidault, Varsovie 26 nov. 1946; AMAE, Relation culturelles, Direction de la Direction generale des Relations culturelles, scientifiques et techniques, Oeuvres diverses - echanges culturels 1945-1959, sygn. 80, Rapport de l'Inspectaeur General des Postes diplomatiques et consulaires sur les Ouevres francaise en Pologne, 4 fevr. 1948, s. 259.

${ }^{5}$ Tekst konwencji - zob. Dziennik Ustaw nr 62, poz. 363.

${ }^{6}$ AMAE, Direction generale des Relations culturelles, scientifiques et techniques, Enseignement 1945-1961, Pologne 1945-1947, sygn. 77, M. Roger Gareau ambssadeur de France en Pologne à G. Bidault, Varsovie 1er juillet 1947. W rzeczywistości Instytut rozpoczął działalność wcześniej, przed oficjalną inauguracją.
} 
W okresie stalinowskim spór o Bibliotekę zaostrzył się w związku ze wzrastającym napięciem w stosunkach polsko-francuskich. Jego efektem było najpierw ekspulsja jedenastu profesorów Instytutu (13 grudnia 1949 r.) w odpowiedzi na aresztowania i wysiedlenia inspektorów oświatowych i nauczycieli polskich we Francji ${ }^{7}$, a następnie (13 stycznia 1950 r.) zawieszenie jego działalności na terytorium Polski. W ten sposób stosunki między Paryżem i Warszawą wchodziły w swój najbardziej konfliktowy etap w powojennej historii. W tych warunkach dyskusja o statusie Biblioteki nie mogła być podjęta.

Pierwsze próby poszukiwania kompromisu we wzajemnych relacjach kulturalnych pojawiły się w 1952 r. 16 czerwca tego roku francuskie MSZ przekazało Ambasadzie PRL w Paryżu nowe propozycje, dotyczące regulacji niektórych problemów $z$ dziedziny kultury i oświaty. Rząd francuski deklarował chęć częściowego wznowienia działalności Instytutu Francuskiego w zamian za koncesje, dotyczące szkolnictwa polskiego we Francji. Odpowiedź Ambasady z 28 lipca 1952 r. na te propozycje była dość chłodna. Zgadzano się na częściowe wznowienie Instytutu Francuskiego w postaci otwarcia bibliotek naukowych w Warszawie i Krakowie, ale nie zaakceptowano propozycji w sprawach oświatowych. Obie strony nie uzgodniły również kwestii funkcjonowania Biblioteki Polskiej w Paryżu mimo, iż rząd polski zadeklarował chęć partycypowania w kosztach restauracji jej budynku ${ }^{8}$.

W latach późniejszych spór o własność Biblioteki między PAU a potem PAN i emigracyjnym Polskim Towarzystwem Historyczno-Literackim (PTHL) zaostrzał się. Jego rozwiązanie było przedmiotem wielu rozmów przedstawicieli dyplomatycznych obu państw. Co ważne, jeszcze na początku lat pięćdziesiątych w ich trakcie zaczęto traktować sprawę Biblioteki i Instytutu jako ściśle związane.

Losy Biblioteki stały się wówczas przedmiotem przewlekłego przewodu sądowego, do którego obie strony skrupulatnie się przygotowywały. Władze krajowe stały na stanowisku, że była własnością PAU, który nigdy nie uznał prawomocności wzmiankowanego wcześniej aktu dzierżawy z 13 czerwca 1945 r. Koła emigracyjne we Francji utworzyły w lipcu 1946 r. PTH-L, które - zdaniem Warszawy - usiłowało występować jako dawne stowarzyszenie o tej nazwie, rozwiązane w 1893 r. Wytoczyło ono (wraz z Zjednoczeniem Polskim Rzymsko-Katolickim) w 1951 r. PAU proces o Bibliotekę uznając się za jej właściciela. W 1954 r. sąd ustanowił francuskiego zarządcę Biblioteki ${ }^{9}$, co bynajmniej nie kończyło sporu.

${ }^{7}$ Archiwum Ministerstwa Spraw Zagranicznych (dalej: AMSZ), z. 8, t. 213, w. 15, k. 372-376. Zgodnie $z$ tą decyzją Polskę mieli do 15 grudnia 1949 r. do północy opuścić następujący profesorowie Instytutu: Andre Rougon, Andre Lasserez, Francois Gregoire, Denise Bouladoux, Claude Manhes, Francois Schnell, Michel Gustin, Henri Baus, Jean Bourilly, Jean Palducci, Louis Bernard.

${ }^{8}$ AMAE, Relation culturelles, Direction generale des Relations culturelles, scientifiques et techniques, Oeuvres diverses - echanges culturels 1945-1959, sygn. 248, Aide-memoire [b.d.], k. nlb.

${ }^{9}$ AMSZ, z. 8, t. 821, w. 59, Biblioteka Polska w Paryżu [1957], k. 83; AMSZ, z. 8, t. 824, w. 60, Załącznik 1. Notatka w sprawie Biblioteki Polskiej w Paryżu, k. 40. 
Władze warszawskie ustaliły dalszą linię postępowania w trakcie rozmów kierownictwa polskiego Ministerstwa Spraw Zagranicznych $z$ adwokatem Joëlem Nordmanem $z$ marcu 1955 r. Polegała ona na przeprowadzeniu dowodu, że dawne Towarzystwo Historyczno-Literackie zostało rozwiązane, a wówczas istniejące nie było jego sukcesorem i nie miało zatem legitymacji czynnej w procesie. W sprawie tej, po dyskusji zdecydowano w dalszym ciagu podtrzymywać tezę o istnieniu PAU w Krakowie, mimo powstania na jego gruzach Polskiej Akademii Nauk (PAN). To stanowisko było o tyle wygodne, że przeciwnik nie mógl forsować argumentu o tym, iż wobec rozwiązania PAU mienie jego powinno było przejść na komitet miejscowy, względnie - wrócić do Towarzystwa, występującego w charakterze powoda. Nie wykluczano jednak, że w dalszym ciągu procesu konieczna będzie zmiana tej argumentacji ${ }^{10}$.

Wyrok w toczącym się procesie zapadł w Izbie Pierwszej Wydziale Pierwszym Sądu Cywilnego Departamentu Sekwany w dniu 21 września 1955 r. Sąd uznał, iż dawne PTH-L zostało rozwiązane $z$ woli członków i przetrwało jedynie dla potrzeb związanych $z$ likwidacją, zakończoną podpisaniem odpowiedniego aktu 16 stycznia $1893 \mathrm{r}$. Zwołanie zgromadzenia ogólnego dawnego stowarzyszenia, co nastąpiło w lipcu 1946 r. zostało dokonane przez osoby do tego nieupoważnione, które nie łączyły $z$ nim żadne więzy prawne. Działalność powoda została uznana jako nie do przyjęcia, odrzucono ją i uchylono jego żądania, cele i wnioski. Sąd ponadto orzekł, iż sprawujący tymczasowy zarząd nad dobrami Biblioteki (jako administrator sądowy) adwokat będzie prawomocnie zwolniony $z$ tych obowiązków $Z$ chwilą ich przekazania uprawnionemu przedstawicielowi PAU. Nastąpiło zapieczętowanie pomieszczeń Biblioteki ${ }^{11}$. Na tym konflikt jednak się nie zakończył, gdyż Towarzystwo wniosło apelację od wyroku.

$\mathrm{W}$ sporze tym władze warszawskie starały się zapewnić sobie poparcie francuskich czynników rządowych. Wyobrażano sobie, że Quai d'Orsay może wywrzeć dyskretną presję na sąd w celu utrzymania w mocy wyroku korzystnego dla władz krajowych. Ceną miała być zgoda na otwarcie (w części lub całości) Instytutu Francuskiego w Warszawie. Ustosunkowując się do tej propozycji Departament Europy w paryskiej centrali MSZ stwierdzał w notatce $z 8$ grudnia 1955 r., iż uważa za niewłaściwe stwarzanie przez stronę polską iunctim między otwarciem Instytutu Francuskiego a kwestią Biblioteki Polskiej w Paryżu. Problem ten miał rozstrzygnąć niezależny sąd francuski, podczas gdy kwestia Instytutu zależała jedynie od dobrej woli rządu polskiego. Rząd francuski nie mógł w tej sprawie dać jakiejkolwiek satysfakcji żądaniom polskim do momentu otrzymania wyroku sądowego ${ }^{12}$.

${ }^{10}$ AMSZ, z. 8, t. 829, w. 60, Notatka dla tow. Ministra Skrzeszewskiego z 31 marca 1955 z konsultacji $z$ adwokatem Nordmanem w sprawach procesowych, prowadzonych na terenie Francji, k. 12.

${ }^{11}$ AMSZ, z. 8, t. 829, w. 60, Wyrok z dnia 21 września 1955 r. zapadły w Izbie Pierwszej Wydziale Pierwszym Sądu Cywilnego Departamentu Sekwany w sprawie Polskie Towarzystwo HistorycznoLiterackie contra Polska Akademia umiejętności w Krakowie, k. 146.

${ }^{12}$ AMAE, Europe 1944-1960, Pologne, vol. 203, Direction générale Politique, Europe, sous-Direction d'Europe orientale, Note pour la Direction des Realtions Culturelles, le 8 décembre 1955, k. 209. 
W związku ze spodziewanym rozpatrzeniem przez sąd wspomnianej apelacji wysiłki dyplomatyczne i naciski Warszawy na Paryż nie ustawały. 22 mraca 1956 r. ambasador Polski Stanisław Gajewski przekazał ministrowi spraw zagranicznych Christianowi Pineau aide-memoire, w którym stwierdzano, iż rząd polski gotowy jest otworzyć bibliotekę przy Instytucie Francuskim w Warszawie jeśli jednocześnie Biblioteka Polska w Paryżu powróci do swego prawnego właściciela (PAU). Francuskie MSZ uznało te formułę jako nie do przyjęcia przede wszystkim $z$ tego powodu, iż Paryż chciał dyskutować nie o otwarciu w Warszawie biblioteki, lecz Instytutu ${ }^{13}$.

Ważna rozmowa na ten temat odbyła się 19 lipca 1956 r. w Paryżu z udziałem S. Gajewskiego, attaché ambasady do spraw kulturalnych i trzech urzędników Quai d'Orsay. Dotyczyła ona wielu innych spraw, w tym przygotowań do wizyty premiera Józefa Cyrankiewicza w Paryżu. W jej trakcie ambasador Polski wysunął koncepcję odsunięcia od Biblioteki Polskiej dotychczasowych gospodarzy oraz przydzielenia bibliotekarza francuskiego (delegata Bibliothèque Nationale) dla wyłącznego zarządu do chwili ostatecznego sądowego przekazania jej PAU. Francuscy rozmówcy obiecali przedstawić sprawę ministrowi Ch. Pineau, ale jednocześnie naciskali na wyznaczenie daty otwarcia Instytutu Francuskiego w Warszawie na początek 1956 r. $^{14}$. W toku dalszych rozmów w lipcu 1956 r. wysunęli wobec polskiej propozycji zastrzė̇enia natury prawnej (bibliotekarz mógł być wprowadzony decyzją sądu a nie władzy wykonawczej). Nie stawiali natomiast sprzeciwu wobec wprowadzenia przedstawiciela PAU dla sporządzenia inwentarza Biblioteki. Strona polska deklarowała zgodę na otwarcie Instytutu Francuskiego w Warszawie 1 listopada 1956 r. $^{15}$.

Jak się okazało na przeszkodzie w realizacji tego scenariusza stanął wyrok zapadły w ciągnącym się niemal trzy lata procesie apelacyjnym, który rozpoczął się 26 września 1956 r. Odbywał się on w atmosferze nieprzychylnej dla Warszawy kampanii propagandowej w prasie, zainicjowanej przez środowiska emigracyj$n \mathrm{e}^{16}$. Obserwatorem procesu $\mathrm{z}$ ramienia PAN był prof. Bogusław Leśnodorski ${ }^{17}$.

${ }^{13}$ M. de Leusse, Ambassadeur de France a Varsovie au Ministre des Affaires étrangeres, Varsovie, 5 avril 1956, Documents Diplomatiques Français (dalej: DDF), 1956, t. I (1er janvier-30 juin), Paris 1988, nr 219.

${ }^{14}$ AMSZ, z. 8, t. 697, w. 52, Wyciąg korespondencyjny z Paryża nr 12634, 12 lipca 1956 r., k. 61-63; tamże, Notatka M. Żuławskiego radcy ds. kulturalnych przesłana przez Gajewskiego z rozmowy $z$ ministrem Daridan na Quai d’Orsay 10 lipca 1956 r., k. 65 i n.

${ }^{15}$ AMSZ, z. 8, t. 697, w. 52, Wyciąg korespondencyjny nr 12952 z Paryża z dnia 17 lipca 1956 r., k. nlb.

${ }^{16}$ Zob. m.in. Sprawa własności Biblioteki Polskiej przed Sądem Apelacyjnym, „Narodowiec” 1956, nr 229; Prokurator wysuną wniosek o dodatkowe badania, „Narodowiec” 1956, nr 277.

${ }^{17}$ Archiwum Polskiej Akademii Nauk w Warszawie (dalej: APAN), Materiały Bogusława Leśnodorskiego, sygn. III-269/118, Notatka w sprawie posiedzenia sądowego w sprawie Biblioteki Polskiej w dniu 21 listopada 1956 r., k. 1. Publicznie wyraz swemu stanowisku dał Leśnodorski w artykule Jak i dalczego powstał spór o Bibliotekę Polska w Paryżu, zamieszczonym w „Expressie Wieczornym” z 27 grudnia 1956, nr 310. Streszczało się ono w nieuznawaniu praw „pewnej grupy emigracyjnej” występującej jako PTH-L. 
Argumentacja adwokatów występujących w imieniu PTH-L i Zjednoczenia Polskiego Rzymsko-Katolickiego, skupiła się na politycznej stronie sporu. Argumenty prawne zmierzały do udowodnienia, iż Towarzystwo zostało zalegalizowane w latach 1946 -1951 i w związku $z$ tym sąd nie powinien w ogóle rozpatrywać kwestii jego istnienia, ciagłości prawnej itp. Ponadto podnoszono charakter prywatno-prawny PAU w przeciwieństwie do państwowego statusu PAN jako jej sukcesora ${ }^{18}$.

19 grudnia 1956 r. sąd zadecydował o konieczności powołania komitetu ekspertów dla ustalenia sytuacji prawnej PAU i rozstrzygnięcia kwestii likwidacji PTH-L. Nakazano zdjęcie pieczęci $z$ Biblioteki, których nałożenie było konsekwencją wcześniejszego wyroku (nastapiło to 25 lutego 1957 roku). Sąd zwrócił się ponadto do francuskiego MSZ o konsultację sprawy własności Biblioteki w świetle polsko-francuskiej konwencji kulturalnej z 1947 r. Opinia nie była zadowalająca dla Warszawy. Stwierdzono w niej, iż zawierając ją, rząd francuski nie uznał tym samym przynależności Biblioteki do PAU. Władze PRL kwestionowały tę ocenę wskazując na wyraźny zapis zawarty w punkcie 7a (cytowany wcześniej) konwencji. Ponadto polemizowały $z$ niejasnościami, zawartymi we wzmiankowanej opinii, dotyczącymi sytuacji prawnej PAU ${ }^{19}$. W zaistniałej sytuacji Francuzi nie mogli liczyć na pozytywne załatwienie kwestii swego Instytutu w Warszawie. Władze polskie jako próbę przeciągania załatwiania sprawy Biblioteki uznały zgłoszoną w grudniu 1956 r. propozycję otwarcia Instytutu Polskiego we Francji ${ }^{20}$. Jako połowiczny sukces Warszawy uznać należy eksmisję Uniwersytetu Wolnej Europy z gmachu Biblioteki jako wprowadzonego tam bez wiedzy zarządcy sądowego ${ }^{21}$.

Polskie władze państwowe zmierzały w dalszym ciągu do wywierania nacisku na Paryż w celu zapewnienia sobie korzystnego rozstrzygnięcia w tym sporze. Ponadto Ambasada PRL starała się wykorzystać sieć kontaktów w środowiskach kulturalnych i naukowych, aby przekonać polskie środowiska emigracyjne, iż po przejęciu Biblioteki władze warszawskie nie zamierzają stworzyć $\mathrm{Z}$ niej kolejnego rez̈imowego ośrodka propagandy ${ }^{22}$.

Impas nie został jednak przełamany. Kwestie Instytutu i Biblioteki nadal były traktowane przez stronę polską jako nierozerwalne ${ }^{23}$.

\footnotetext{
${ }^{18}$ AMSZ, z. 8, t. 829, w. 60, Niektóre uwagi dotyczące procesu o Bibliotekę Polską, Paryż 19 X 1956 , k. 141.

${ }^{19}$ AMSZ, z. 8, t. 821, w. 59, Biblioteka Polska w Paryżu, k. 105-106; AMSZ, z. 23, t. 174, w. 15, Notatka Ogrodzińskiego z 1 sierpnia 1957 r., k. nlb.; Sąd nakazał zdjęcie pieczęci z Biblioteki Polskiej w Paryżu, „Narodowiec” 1956, nr 300.

${ }^{20}$ AMSZ, z. 8, t. 821, w. 59, Notatka w sprawie obecnej fazy stosunków polsko-francuskich [grudzień 1956], k. nlb.

${ }^{21}$ AMSZ, z. 8, t. 824, w. 60, Załącznik 1. Notatka w sprawie Biblioteki Polskiej w Paryżu, k. 40.

${ }^{22}$ AMSZ, z. 8, , t. 817, w. 59, Raport polityczny za I półrocze 1957 r., k. nlb.

${ }^{23}$ Zob. m.in. M. Burin de Roziers a M. Couve de Murville, Varsovie, 16 décembre 1958, w: DDF 1958, t. II, nr 423.
} 
Dialog na ten temat zaczął się żywiej rozwijać nie tylko za sprawą procesu sądowego, ale również w związku $z$ dyskusją nad dokumentem, który miał zastąpić wygasającą w 1957 r. konwencję kulturalną. Paryż, wobec nadal nierozwiązanej kwestii Instytutu Francuskiego w Polsce, skłaniał się do podpisania zamiast niej, na okres przejściowy, wspólnej deklaracji obu rządów. Takie stanowisko zajął dyrektor polityczny Qaui d'Orsay Daridan w rozmowie $z$ ambasadorem S. Gajewskim w dniu 10 lipca 1956 r. Ten ostatni przypomniał propozycję Warszawy, według której wspólna deklaracja winna powołać się na konwencję kulturalną z 1947 r., po czym miało nastąpić jej faktyczne dostosowanie do aktualnych potrzeb na posiedzeniach komisji mieszanej. Francuzi jednak byli bardziej ostrożni, choć nie sprzeciwiali się, aby w projektowanej deklaracji wspomnieć konwencję z 1947 r. Dyskutowano również na temat stypendiów, wymiany książek i publikacji naukowych oraz nauczania języka francuskiego w Polsce ${ }^{24}$. 17 lipca Warszawa wyraziła zgodę na zasadę deklaracji dwustronnej; obie strony miały przygotować własne teksty do dalszych negocjacji ${ }^{25}$.

W świetle innych zachowanych dokumentów polskiego MSZ ta aprobata Warszawy była ściśle związana $z$ rachubami na mocniejsze zaangażowanie się francuskich czynników oficjalnych w toczący się wzmiankowany wcześniej proces sądowy, dotyczący własności Biblioteki Polskiej w Paryżu. Niekorzystne orzeczenie w tej sprawie skłaniało władze polskie do usztywniania stanowiska w kwestii konwencji kulturalnej. W notatce „w sprawie obecnej fazy stosunków polsko-francuskich” z 29 grudnia 1956 r., przeznaczonej dla kierownictwa ministerstwa, jego wysoki funkcjonariusz, Henryk Birecki pisał, iż należy dążyć do dalszego jej przedłużenia w kształcie $z 1947$ r. Za szczególnie korzystny uznawał artykuł siódmy, stawiający - jego zdaniem - iunctim między działalnością Instytutu Francuskiego i Biblioteki Polskiej. Wygaśnięcie konwencji pozbawiało władze PRL cennego instrumentu dla korzystnego rozwiązania tej kwestii. „W przypadku gdyby Francuzi nie zgodzili się na przedłużenie obecnej konwencji kulturalnej - pisał Birecki - należałoby zaproponować jej tekst jako bazę do dyskusji nad nową konwencją" ${ }^{26}$. W odpowiedzi na polskie propozycje w dniu 9 marca 1957 r. Daridan przedstawił Gajewskiemu projekt wspólnej deklaracji. Ponadto oświadczył, iż nie widzi możliwości podpisania czy przedłużenia konwencji (wygasała w czerwcu 1957 r.) dopóki nie będzie otwarty Instytut Francuski w Polsce ${ }^{27}$. Intensywne rozmowy w tej sprawie prowadzono jeszcze w kwietniu 1957 r., ale stanowisko Quai d’Orsay było twarde. Co ciekawe manifestowano je nie tylko wobec Warszawy, ale równiė $\mathbf{w}$ obrębie francuskich instytucji rządowych. W piśmie Departamentu Politycznego (Wydział Europy

24 AMSZ, z. 8, t. 697, w. 52, Notatka M. Żuławskiego radcy do spraw kulturalnych z rozmowy Gajewskiego z ministrem Daridan, 13 lipca 1956, k. 65.

${ }^{25}$ AMSZ, z. 8, t. 697, w. 52, Dalsza rozmowa $z$ Daridan, 17 lipca 1956 r. Wyciąg korespondencyjny nr 12952, k. nlb.

${ }^{26}$ AMSZ, z. 8, t. 821, w. 59, Notatka w sprawie obecnej fazy stosunków polsko-francuskich, 29 grudnia 1956 r., k. nlb.

${ }^{27}$ AMSZ, z. 8, t. 824, w. 60, Wyciąg korespondencyjny nr 2744 z Paryża 11 marca 1957, k. nlb. 
Wschodniej) francuskiego MSZ do sekretarza stanu z 16 maja 1957 r. pisano o impasie $\mathrm{w}$ rozmowach na temat konwencji, ale jednocześnie stwierdzano, i $\dot{z}$ nie powoduje to zahamowania i tak już realizowanej wymiany kulturalnej i naukowej $^{28}$. Symptomatyczne, iż podobna opinia o pomyślnym rozwoju tych relacji, mimo braku formalnego oparcia w „Zamrożonej” i wygasłej konwencji kulturalnej z 1947 r., znalazła się w raporcie politycznym ambasady PRL w Paryżu Z września $1957 \mathrm{r}^{29}$

Ostatecznie deklaracja polsko-francuska o współpracy w dziedzinie kulturalnej została przyjęta 9 lipca 1957 r. w formie wymiany not między Quai d'Orsay i ambasadą PRL w Paryżu. Była efektem kompromisu. Na większe ustępstwa poszła Warszawa. We wstępie stwierdzano: „Rząd Polski i Rząd Francuski - ożywione chęcią znalezienia środków, które przyczyniłyby się do ogólnego polepszenia wzajemnych stosunków we wszystkich dziedzinach - uważają, że stosunki kulturalne stanowią szczególnie wdzięczne pole dla zamanifestowania obustronnej dobrej woli”. W tym celu postanowiono kontynuować wysiłki „mające na celu rozwijanie za obopólną zgodą wzajemnych stosunków kulturalnych za pośrednictwem właściwych instytucji oficjalnych" (punkt 1). Zdecydowano (punkt 2) pogłębić wzajemne zrozumienie między obydwoma narodami za pomoca , „wszelkich właściwych środków, a w szczególności przez:

a) swobodne poruszanie się osób pomiędzy obydwoma krajami. Oba rządy wyrażają zadowolenie $z$ dotychczas osiągniętych na tym polu wyników;

b) sprowadzanie i rozpowszechnianie w każdym $z$ obydwu krajów książek, dzienników i czasopism literackich, artystycznych, naukowych lub technicznych przy zastosowaniu wzajemności”.

Sformułowanie zawarte w punkcie 2a polscy negocjatorzy próbowali wyeliminować (bezskutecznie) $z$ tekstu deklaracji.

Jednak największe kontrowersje wzbudzał punkt 3. Ostatecznie zapisano w nim, iż rządy postanawiają: „Popierać znajomość i używanie języka francuskiego w Polsce i języka polskiego we Francji:

a) przez rozwijanie nauczania języka francuskiego w polskich szkołach średnich i wyższych oraz nauczania języka polskiego we francuskich szkołach średnich i wyższych. Częsta wymiana poglądów między obydwiema stronami winna umożliwić wzajemne porozumienie w sprawach o szczególnym znaczeniu, a mianowicie w sprawie nauczania języka polskiego, $z$ którego mają prawo korzystać we Francji dzieci polskiego pochodzenia uczęszczające do szkół podstawowych;

b) przez popieranie tworzenia katedr i lektoratów języka i literatury francuskiej w Polsce oraz języka i literatury polskiej we Francji, a także przez przyspieszenie wznowienia działalności lub utworzenia instytutów czy instytucji badawczych polskich we Francji i francuskich w Polsce”.

\footnotetext{
${ }^{28}$ AMAE, EU 1956-1960, Pologne, vol. 231, Direction générale Politique, Service d’Europe orientale, Note pour le Secrétaire d'Etat, 16 mai 1957, k. 104.

${ }^{29}$ AAN, KC PZPR XIA/39, Wyciag z raportu politycznego Ambasady PRL w Paryżu za pierwsze półrocze 1957, Warszawa, 7 IX 1957, k. 127.
} 
Przedstawione przez stronę polską brzmienie punkt 3a zawierało sformułowanie o zabezpieczeniu „w drodze współpracy pomiędzy kompetentnymi władzami polskimi i francuskimi nauki języka, literatury, historii i geografii polskiej dla dzieci pochodzenia polskiego zamieszkałych we Francji”. Było ono znacznie bardziej zobowiązujące dla władz francuskich i $z$ tego powodu zostało odrzucone. Kontrowersje wzbudzało również sformułowanie punktu 3b. Polacy chcieli, aby zawarto w nim wyraźną wzmiankę o sprzyjaniu otwarciu Instytutu Francuskiego i przywróceniu władzom warszawskim Biblioteki Polskiej w Paryżu, co zgodnie $z$ ich przewidywaniami, zostało odrzucone. Użyte w ostatecznym tekście określenie „instytucje badawcze” miało „zabezpieczać” stronie polskiej możliwość upominania się o korzystne dla siebie rozwiązanie sprawy Biblioteki. W dalszej części deklaracji rządy zobowiązywały się (punkt 4) „umożliwić obywatelom obydwu państw zapoznanie się z kulturą i osiągnięciami drugiej strony:

a) przez ułatwienie wymiany, kontaktów i współpracy pomiędzy przedstawicielami nauki, literatury, sztuki, teatru, muzyki, filmu i radia;

b) przez rozwijanie współpracy pomiędzy radiem i telewizją francuską i polską, w szczególności jeśli chodzi o wymianę programów;

c) przez zachęcenie do wzajemnego korzystania $z$ uniwersytetów, bibliotek, muzeów i laboratoriów przez studentów, wykładowców, badaczy, techników i uczonych.

d) przez powiększenie ilości stypendiów studenckich i naukowych, przez popieranie w ogóle współpracy pomiędzy obydwoma krajami w dziedzinie naukowej i technicznej.

5. Popierać organizowanie za wspólnym porozumieniem występów artystycznych, tournee teatralnych, wyświetlanie filmów, urządzanie wystaw artystycznych, literackich, naukowych i technicznych oraz spotkań sportowych.

6. Ułatwić wymianę dokumentacji, a w szczególności filmów oświatowych i naukowych, jak również sprzedaż, dystrybucję i wymianę filmów o wartości artystycznej”. Na wniosek strony polskiej wprowadzono ponadto punkt 7 stwierdzający, iż nad wykonaniem deklaracji będzie czuwać Komisja Mieszana złożona $z$ delegatów wyznaczonych przez „właściwe władze francuskie i polskie"30.

Bardzo konkretne decyzje, dotyczące współpracy kulturalnej i naukowej zapadły w trakcie rozmów, które toczyły się w Warszawie w dniach 19-21 lutego 1958 r. Delegacji francuskiej przewodniczył Roger Seydoux, szef Dyrekcji do Spraw Kulturalnych we francuskim MSZ, polskiej - wiceminister szkolnictwa wyższego Eugenia Krassowska. Według oceny polskiego MSZ delegacja francuska postanowiła, i $\dot{z}$ wobec istniejącego impasu w sprawie Biblioteki Polskiej w Paryżu i Instytutu Francuskiego w Polsce, należy stworzyć - dla częściowego przynajmniej wypełnienia luki na tym polu - ośrodek studiów francuskich przy

${ }^{30}$ AMSZ, z. 8, t. 824, w. 60, Winiewicz do Cyrankiewicza, Warszawa 8 lipca 1957, k. nlb.; tamże, Propozycje zmian do projektu deklaracji przesłane jako instrukcja Dyrektora Departamentu II H. Bireckiego dla ambasadora Gajewskiego z 28 maja 1957, k. nlb. 
Uniwersytecie Warszawskim. Wybrano UW a nie Polską Akademię Nauk m.in. dlatego, że ułatwiało to kreowanie w przyszłości filii tej placówki w innych miastach (m.in. w Krakowie). Strona francuska przykładała wielką wagę do realizacji tego postulatu, zapewniając wzajemność. Decyzję pozytywną w tej sprawie przekazała w trakcie rozmów Krassowska, która zaczęła jednak ją obwarowywać warunkami - m.in. takim, że kierownikiem ośrodka francuskiego winien być nie Francuz, lecz profesor polski. W tej sytuacji na wniosek Seydoux przerwano obrady celem odbycia konsultacji w delegacjach. Jaki był ich przebieg nie wiadomo. Ich efektem było jednak wypracowanie porozumienia. Zdecydowano, iż kierownikiem ośrodka w Polsce będzie Francuz, a we Francji - Polak. Postanowiono równie $\dot{z}$, że nie będą one miały prawa wydawania dyplomów. Przedstawiciele PAN - uczestnicy rozmów niechętnie godzili się na tworzenie wspomnianego ośrodka przy UW, gdyż Akademia nawiązała już kontakt $z$ Ecole Pratique des Hautes Etudes i pragnęła tam skoncentrować współpracę naukową $z$ Francją. Dzięki rozmowom przygotowawczym przedstawicieli MSZ udało się uniknąć konfliktu na tym tle między przedstawicielami Ministerstwa Szkolnictwa Wyższego i PAN w trakcie obrad. Krassowska wręczyła Seydoux aidemémoire w sprawie Biblioteki ${ }^{31}$. Szef delegacji francuskiej w swej notatce sprawozdawczej $z$ rozmów pisał, iż był pod wrażeniem przyjaznego nastawienia do współpracy $z$ Polską wyrażanego nie tylko przez polskie środowiska intelektualne, ale równie $\dot{z}$ przedstawicieli wład $z, z$ którymi się zetknął ${ }^{32}$.

W rezultacie tych negocjacji przyjęto program wymiany i współpracy kulturalnej między Polską a Francją. Jak już wcześniej wzmiankowano, zdecydowano, iż przy Uniwersytecie Warszawskim zostanie utworzony Ośrodek Studiów nad Cywilizacją Francuską, dostępny dla polskich pracowników nauki, absolwentów szkół wyższych i studentów. Nowa placówka, podległa władzy rektora UW, miała być administrowana przez kierownika naukowego, przybyłego $z$ Francji, zobowiązanego do zapewnienia przyjazdów profesorów francuskich na wykłady, dotyczące zagadnień kulturalnych i technicznych. Obowiązkiem kierownika było organizowanie kolokwiów, przewidzianych programem rocznym. W zamian w VI Sekcji Ecole Pratique des Hautes Etudes (EPHE) przy Uniwersytecie Paryskim postanowiono utworzyć Ośrodek Studiów nad Historią i Cywilizacją Polską, podległy przewodniczącemu tej Sekcji i administrowany przez kierownika naukowego przybyłego $z$ Polski, o kompetencjach podobnych, jak jego odpowiednik w Warszawie ${ }^{33}$.

31 AMSZ, z. 8, t. 946, w. 68, Notatka w sprawie obrad Komisji Mieszanej Polsko-Francuskiej (Warszawa 19-21 luty 1958), k. 79.

${ }^{32}$ AMAE, EU 1956-1960, Pologne, vol. 231, Direction générale Politique, Europe, Service d'Europe orientale, Note a.s. séjour en Pologne de la délégation française venue pour mener des pourparles culturels, 3 mars 1958, k. 135.

${ }^{33}$ AMSZ, z. 8, t. 946, w. 68, Program wymiany i współpracy kulturalnej między Polską a Francją [na lata 1958/59], k. 72-78; AMAE, Relations Culturelles, Enseignement, 298, Aneks nr 2 do komunikatu francusko-polskiego z 21 II 1958 r. Program wymiany i współpracy kulturalnej i naukowej między Francją a Polską na lata 1958-1959, k. nlb. 
Jak widać, sprawa Biblioteki nadal pozostawała nierozwiązanym problemem w stosunkach polsko-francuskich. Sytuacji nie zmieniły również rozmowy mniej oficjalne, odbywane przez niektórych uczonych polskich. W maju i czerwcu 1957 r. prowadził je - za zgodą ambasady PRL w Paryżu - prof. Tadeusz Manteuffel. W Paryżu spotkał się wówczas $z$ przedstawicielami emigracji, m.in. z Jerzym Giedroyciem, Zygmuntem Lubiczem-Zaleskim, Szymonem Konarskim, Wiktorem Żółtowskim i Kajetanem Morawskim. Manteuffel wysunął trzy propozycje mogące być w jego przekonaniu przedmiotem kompromisu: „1. Biblioteka Polska jest własnością Narodu Polskiego. Sprawą dalszych rokowań byłoby ustalenie jaka instytucja w kraju stałaby się dysponentem tej własności. 2 . Przy Bibliotece Polskiej zostaje powołana Rada Naukowa, w której większość mogą stanowić przedstawiciele emigracji. Rada Naukowa byłaby powołana do decydowania w sprawie profilu naukowego Biblioteki, miejsca przechowywania jej zbiorów i obsady personalnej. 3. Możnaby Bibliotece Polskiej nadać charakter Zakładu badającego dzieje emigracji polskiej zarówno we Francji jak innych krajach”. Sprawy jednak nie udało się załatwić w proponowany sposób $b^{34}$.

Wobec zbliżania się momentu wydania wyroku przez Sąd Apelacyjny środowiska emigracyjne po raz kolejny podjęły akcję propagandową w celu uniemożliwienia Warszawie zawładnięcia Biblioteką. Najpoważniejszym elementem tej kampanii było debata we francuskim Zgromadzeniu Narodowym w tej sprawie w dniu 3 czerwca 1959 r., zainicjowana przez René Plevena i jego politycznych przyjaciól. Większością 467 głosów przy 10 wstrzymujących się została przyjęta uchwała (resolution) wzywająca rząd francuski do podjęcia wszystkich możliwych kroków (dispositions) w celu zapewnienia całkowitej swobody Biblioteki Polskiej w Paryżu (,pour maintenir l'entiere liberte de la Bibliotheque”) ${ }^{35}$.

Dla władz warszawskich nie ulegało wątpliwości, iż uchwała parlamentarna miała wpływ na końcowy werdykt Sądu Apelacyjnego ogłoszony 8 lipca 1959 r. Uznał on, iż PTH-L nie jest kontynuacją dawnego towarzystwa a krakowska Akademia Umiejętności nie udowodniła dostatecznie swoich praw do Biblioteki. W tej sytuacji została ona uznana za „res nullus”. Ponadto stwierdzano w nim, iż umowa dzierżawna zawarta przez F. Pułaskiego $z$ Polskim Zjednoczeniem Rzymsko-Katolickim jest nadal ważna do $1963 \mathrm{r}$. Administracja sądowa nad Biblioteką miała być nadal utrzymana. Od wyroku przysługiwało prawo kasacji, które dla PTH-L upływało 10 kwietnia 1960 r. Warszawa zdawała sobie sprawę, że wyrok faktycznie oznacza pozostawanie Biblioteki w rękach emigracji polskiej. $Z$ punktu widzenia prawnego istniała bowiem możliwość przeciaggania procesu w nieskończoność. Szanse jego wygrania oceniano jako nikłe głównie ze względu na ogólnikowość klauzuli rewokacyjnej zawartej w akcie

${ }^{34}$ APAN w Warszawie, Materiały Tadeusza Manteuffla, III-192/118, Sprawozdanie z podróży..., k. $96-97$.

${ }^{35}$ Journal Officiel de la République Française, 1er séance du Mercredi 3 juin 1959. O sporze o Bibliotekę Polską - zob. również: P. Hübner, Siła przeciw rozumowi ... Losy Polskiej Akademii Umiejętności w latach 1939-1989, Kraków 1994, s. 339-345; J. Mond, Towarzystwo Historyczno-Literackie i Biblioteka Polska w Paryżu. Historia i dzień dzisiejszy, „Nauka Polska” 1991, nr 2, s. 98-103. 
darowizny z 1891 r. między PTH-L i PAU. Władze PRL jednak nie dramatyzowały sytuacji uważając, iż placówka ta „nie posiada dla nas przesadnej wartości. Nasza działalność propagandowa - pisano w dokumencie MSZ - kulturalnonaukowa i polonijna może się rozwijać pomyślnie $z$ jej pominięciem wobec istnienia na terenie Francji placówek takich jak Stacja Naukowa PAN, Ośrodek Cywilizacji Polskiej na Sorbonie, polonijne stowarzyszenia kulturalno-społeczne itd. Niemniej, zagadnienie Biblioteki Polskiej ciąży nad stosunkami kulturalnymi polsko-francuskimi, uniemożliwiając ich uregulowanie"36.

W latach późniejszych prowadzono rozmowy w sprawie uregulowania tej kwestii, ale bez większego efektu. W marcu 1960 r. toczyły się one w Paryżu $z$ inicjatywy francuskiego MSZ między H. Bireckim i dyrektorem generalnym Quai d'Orsay Rogerem Seydoux oraz innymi zaproszonymi dyplomatami. Wynikało $z$ nich, iż Francuzi zastanawiali się nad możliwością zawarcia umowy kulturalnej $z$ Polską, co miało pozwolić na otwarcie Instytutu Francuskiego w Warszawie i Krakowie. Dla Bireckiego warunkiem sine qua non zgody na to był zwrot Biblioteki Polskiej w Paryżu. Zdając sobie sprawę z powiązania obu kwestii Francuzi zaproponowali rozwiązanie, zgodnie $z$ którym Biblioteka zostałaby przekazana pod nadzór rektora Uniwersytetu Paryskiego. Dyrektor byłby przysłany $z$ kraju. Proponowano powołanie Rady przy Bibliotece w składzie uzgodnionym $z$ władzami warszawskimi. To miało umożliwić Quai d’Orsay nacisk na kręgi emigracyjne oraz neutralizowanie niektórych francuskich kół politycznych. Birecki zwrócił uwagę Francuzów, i $\dot{z}$ „każde połowiczne załatwienie sprawy implikuje absolutną wzajemność w analogicznym potraktowaniu przez nas Instytutów Francuskich w Polsce" ${ }^{37}$.

Znana dokumentacja archiwalna nie wskazuje na to, aby propozycje francuskie zostały przyjęte. W tej sytuacji taktyka Paryża w rozmowach na tematy wymiany kulturalnej i naukowej $z$ Polska polegała na tworzeniu nowych form organizacyjnych, stanowiących substytut Instytutu Francuskiego. Efektem tych zabiegów było powstanie wspomnianych już czytelni francuskich w Warszawie i Krakowie, Ośrodka Kultury Francuskiej przy UW czy Centrum Dokumentacji Naukowo-Technicznej. Sprawa Biblioteki stanowiła jednak „dyżurny” argument przy okazji dyskusji na temat rozszerzenia działalności tych instytucji lub kreowania nowych. W 1964 r. użyto go w trakcie rozmów na temat utworzenia drugiego Ośrodka Kultury Francuskiej na jednym $z$ polskich uniwersytetów. Francuzi przypuszczali wówczas, iż ich polscy rozmówcy w rzeczywistości nie są zbytnio zainteresowani korzystnym dla siebie rozwiązaniem kwestii Biblioteki

${ }^{36}$ AMSZ, z. 8, t. 824, w. 60, Załącznik 1. Notatka w sprawie Biblioteki Polskiej w Paryżu, k. 40; AMAE, Relations culturelles et techniques, Pologne, vol. 1815, Note sur la Bibliotheque Polonaise de Paris (situation du probleme en aout 1965), k. nlb.; Sąd odrzucił powództwa obydwu stron, utrzymując na razie stan obecny, „Narodowiec” 1959 , nr 161.

${ }^{37}$ AMSZ, z. 23, t. 174, w. 15, Notatka Rapackiego z nieoficjalnych rozmów $z$ przedstawicielami francuskiego MSZ w sprawie możliwości rozwiązania spornych problemów polsko-francuskich w dziedzinie kulturalnej, Warszawa 17 marca 1960, k. nlb. 
$z$ powodu trudności finansowych, jakie by to spowodowało ${ }^{38}$. Trudno powiedzieć, na ile te przypuszczenia odpowiadały rzeczywistości. Faktem jest jednak, $\mathrm{iz}$ te sporne problemy, dzięki obustronnej woli współpracy, nie zdołały zahamować kontaktów polsko-francuskich w dziedzinie kultury i nauki.

Po raz kolejny sprawa Biblioteki wróciła jako temat rozmów na najwyższym szczeblu po 1970 r. Problem ten został poruszony m.in. w trakcie wizyty Edwarda Gierka we Francji w jego rozmowie $z$ prezydentem Georgesem Pompidou 3 października $1972 \mathrm{r}^{39}$ Nie doprowadziła ona do żadnych zdecydowanych konkluzji poza jedynie wskazaniem na konieczność poufnych rozmów dyplomatycznych w tej sprawie.

Dążenie do podporządkowania Biblioteki Warszawie było jednak stałym elementem rozmów dyplomatycznych, toczonych w tym okresie. Już w trakcie polsko-francuskich konsultacji politycznych w Warszawie 9 i 10 maja 1973 r. temat ten powrócił, lecz nie zapadły żadne decyzje ${ }^{40} .15$ lutego 1974 r. sprawa Biblioteki była przedmiotem rozmowy ambasadora Francji w Warszawie Louisa Dauge'a $z$ dyrektorem IV Departamentu polskiego MSZ Henrykiem Sokolakiem. Według zachowanej notatki, sporządzonej przez tego ostatniego, miał on podkreślić „pełną odpowiedzialność władz francuskich za niszczenie zbiorów, które mają wartość nie tylko dla Polski, ale i dla Francji. Stwierdziłem, że po uznaniu przez sąd francuski, że Biblioteka Polska jest «niczyją» i przekazaniu jej do dyspozycji władz, te traktują ją naprawdę jak «niczyją», a obserwator polski często nie może się oprzeć wrażeniu, że w imię solidarności $z$ kilku przeciwnikami Polski, którzy zajęli bezprawnie Bibliotekę, niektórzy przedstawiciele Francji woleliby, aby Biblioteka raczej rozpadła się i zgniła, niż dostała się pod opiekę polskich naukowców. Podkreśliłem znaczenie jakie przywiązujemy do rozmów w sprawie Biblioteki [...]. Dauge był zmieszany. Usiłował tłumaczyć postępowanie władz chęcią rozwiązania w sposób «biologiczny» kilku spraw ludzkich. Później na pewno Bibliotekę nam przekażą. Zapytałem go, czy jest przekonany o tym, że po «biologicznym» rozwiązaniu spraw ludzi, będzie jeszcze co przekazywać $z$ pozostałości Biblioteki. Obiecał przekazać moją interwencję do Paryża"41.

24 sierpnia 1974 r. strona polska złożyła we francuskim MSZ aide-mémoire $\mathrm{w}$ tej sprawie. Proponowano w nim przekazanie Biblioteki na stałe - bez przesądzania prawa własności - w formie prawa wieczystego użytkowania jednej $Z$ głównych bibliotek polskich (Bibliotece Narodowej lub Bibliotece Jagiellońskiej), zgodnie ze stosowaną we Francji procedurą. Taka decyzja ustanawiałaby instytucję kuratorów Biblioteki, którymi mogliby być rektorzy UW i UJ. Nadaliby oni statut tej książnicy i sprawowaliby ogólny nadzór. Ów statut zawierałby

${ }^{38}$ AMAE, Relations culturelles et techniques, Pologne, vol. 1815, Note en date du 17 avril $1964 \mathrm{a} / \mathrm{s}$ Bibliotheque polonaise de Paris.

39 AMAE, Europe 1971-1976 juin, Pologne, 3487, Entretien en tete entre le President de la Republique et M. Gierek, le 3 octobre. [spr. tytuł, sygnaturę]; zob. również: AN, AG/5(2)/1016

${ }^{40}$ AMAE, Europe 1971-juin 1976, 3485, G. de Courcel, Paris, le 16 mai 1973, circulaire no 282, tel. au dep., Consultations politiques franco-polonaises (Questions bilaterales).

${ }^{41}$ AMSZ, 20/79, w.3, Notatka informacyjna, Warszawa 21 II 1974. 
kilka najważniejszych postanowień, w tym gwarantowałby tej instytucji własną nazwę i autonomię jako wyodrębnionej placówce zagranicznej danej Biblioteki. Proponowano powołanie Komitetu Naukowego Biblioteki Polskiej, złożonego $Z$ wybitnych osobistości polskich i francuskich. Postulowano ponadto stworzenie komitetu ekspertów przez stronę polską i francuską dla opracowania szczegółowych propozycji w tej sprawie ${ }^{42}$.

Po raz kolejny problem ten wypłynął w trakcie rozmów, prowadzonych w Warszawie $z$ przewodniczącym Rady Państwa - Henrykiem Jabłońskim i ministrem spraw zagranicznych Stefanem Olszowskim przez ministra stanu Michela Poniatowskiego we wrześniu 1974 r. Ten ostatni, kuzyn ówczesnego prezesa THL, Andrzeja Poniatowskiego, miał wyrazić pogląd, że problem będzie rozwiązany pozytywnie dla Polski w przeciagu 3-4 lat. Zapowiedział rychłą odpowiedź na polskie aide-mémoire, co strona polska oceniała jako „krok naprzód”. Wyraził pogląd, iż w przypadku „rozwiązania siłowego” THL może zabrać swoje kolekcje, które są w Bibliotece najcenniejsze. Postulował szukanie rozwiązania $\mathrm{w}$ gronie podmiotów reprezentujących państwo francuskie (Bibliothèque Nationale), polskie (odpowiedni organizm „equivalent”) i THL. Jego zdaniem sprawa była bardzo drażliwa dla emigracji polskiej $\mathrm{i}-\mathrm{z}$ tego powodu - również dla władz francuskich ${ }^{43}$.

Koncepcja takiego trzystronnego spotkania, jaką zaproponował M. Poniatowski była przedmiotem studiów w Warszawie. Wydaje się, że ich wynik okazał się negatywny. Świadczy o tym zachowane w aktach polskiego MSZ sprawozdanie $Z$ warszawskich rozmów przywódców PRL $Z$ ministrem spraw zagranicznych Francji Jeanem Sauvagnargues'em prowadzonych od 26 do 28 lutego 1975 r. Potwierdził on aktualność tej propozycji i stwierdził, iż strona francuska oczekiwała odpowiedzi na nią. Jednak - jak wynika $z$ cytowanego dokumentu - wiceminister spraw zagranicznych Józef Czyrek w czasie konsultacji w Paryżu odrzucił możliwość takich negocjacji ${ }^{44}$.

Oficjalna odpowiedź francuska na polskie aide-mémoire została zawarta w nocie $z 9$ czerwca 1975 r. Stwierdzano w niej, iż zadowalające rozwiązanie sprawy Biblioteki jest możliwe jedynie przy udziale trzech zainteresowanych stron. Proponowano rozważenie możliwości powołania trójstronnej grupy ekspertów, która zbadałaby możliwości osiąnnięcia porozumienia zgodnego $\mathrm{Z}$ interesami wszystkich stron i stworzenia warunków dla lepszej znajomości obu narodów ${ }^{45}$.

${ }^{42}$ AMSZ, 1/83, w. 2, Informacja na temat Biblioteki Polskiej w Paryżu, Warszawa, 31 października 1976.

${ }^{43}$ AMSZ, 20/79, w.3, Pilna notatka S. Olszowskiego, dotycząca wyników wizyty Ministra Stanu Republiki Francuskiej Michel Poniatowskiego; AMAE, Europe 1971-juin 1976, 3489, Entretiens du ministre d'Etat avec M. Olszowski, Ministre des Affaiores Etrangeres 6 septembre 1974; tamże, Dague, Varsovie, le 11 septembre 1974. Objet: Bibliotheque Polonaise de Paris.

${ }^{44}$ AMSZ, 17/81, w. 2, Wizyta ministra spraw zagranicznych Francji Jean Sauvagnargues'a w Polsce 26-28 lutego 1975 r.

${ }^{45}$ AMSZ, 1/83, w. 2, Informacja na temat Biblioteki Polskiej w Paryżu... 
Dla dalszych negocjacji istotne znaczenie miało podpisanie w lipcu $1975 \mathrm{r}$. przez A. Poniatowskiego w imieniu THL, aktu dzierżawy Biblioteki Polskiej na 18 lat. Wcześniej, bo w kwietniu 1975 r., stanął on na czele Centralnego Funduszu Kultury Polsko-Francuskiej, $z$ siedzibą w gmachu Biblioteki ${ }^{46}$.

Strona polska w nocie $z 31$ października 1975 r. zaakceptowała spotkanie grupy roboczej dla zbadania całokształtu problemu i zaproponowała datę 17 listopada jako jego termin. Francuzi wyraźnie zwlekali $z$ rozpoczęciem tych pertraktacji, do których nie doszło.

Sprawa powróciła po raz kolejny w trakcie oficjalnych dwustronnych konsultacji politycznych $z$ udziałem ministra spraw zagranicznych Stefana Olszowskiego, jakie odbyły się we Francji 18-20 lutego 1976 r. W zachowanych w polskich i francuskich archiwach informacjach na ten temat istnieje pewna rozbieżność. 20 lutego rano doszło do wymiany zdań na ten temat między szefem polskiej dyplomacji a Jacques'em Dupuy, zastępcą dyrektora generalnego stosunków kulturalnych, naukowych i technicznych we francuskim MSZ, w obecności ministra Sauvagnargues’a. Francuz przypomniał, iż Paryż zgodził się na spotkanie delegatów trzech zainteresowanych stron, po zakończeniu konsultacji ekspertów. Olszowski odpowiedział, iż Warszawa zgadza się na pozostawienie tego problemu do przyszłych konsultacji „reprezentantów obu rządów w obecności obecnych użytkowników" (occupants actuelle): taka fomuła jest do zaakceptowania ${ }^{47}$. W note de synthese, powstałej po wizycie stwierdzano, iż polski gość zaakceptował koncepcję spotkań ekspertów, reprezentujących wszystkie trzy zainteresowane strony. Francuzi obiecali zaproponować w najbliższej przyszłości termin takiego spotkania ${ }^{48}$. Wedle ,pilnej notatki” polskiego MSZ w sprawie Biblioteki francuski minister miał stwierdzić, iż niedługo winny się zakończyć konsultacje wewnętrzne, po których zostanie zaproponowana data spotkania przedstawicieli władz francuskich i polskich w obecności [podkr. - DJ, MP] przedstawicieli THL ,co jest ustępstwem wobec nas $z$ bronionej przez lata przez Francuzów koncepcji rozmów trójstronnych" ${ }^{* 9}$. Akceptacja dla tej formuły, polegającej na „dyskusji przedstawicieli obu rządów w obecności użytkowników [Biblioteki]", została potwierdzona przez polskich ekspertów z MSZ w trakcie rozmów $z$ ich francuskimi odpowiednikami 22 lutego 1976 r. Problemem dalszych ustaleń miał być termin pierwszego spotkania ${ }^{50}$.

Czy owe różnice $\mathrm{w}$ cytowanych dokumentach mają jedynie drugorzędne znaczenie, czy też są efektem bardziej znaczących różnic stanowisk? Trudno na tak sformułowane pytanie udzielić zdecydowanej odpowiedzi. Wiadomo jednak, iż formuła o spotkaniu „ekspertów i prawników”, reprezentujących trzy strony

\footnotetext{
${ }^{46}$ Tamże.

${ }^{47}$ AMAE, Europe 1971-juin 1976, 3487, Consultation politiques franco-polonaise, vendredi 20 fevrier. Seance du matin. Questions bilaterales.

${ }^{48}$ AMAE, Europe 1971-juin 1976, 3487, Note de synthese, Paris, le 12 février 1976.

${ }^{49}$ AAN, KC PZPR, mikr. 2906 [d. sygn. 1790], Pilna notatka o oficjalnej wizycie we Francji Ministra Spraw Zagranicznych PRL (18-20 lutego 1976 r.), k. 275.

${ }^{50}$ AMSZ 31/82 w. 1, Notatka z rozmowy ekspertów odbytej w dniu 22 lutego 1976 r. w MSZ Francji.
} 
zainteresowane, była używana konsekwentnie we francuskich dokumentach dyplomatycznych m.in. przy okazji wizyty we Francji premiera Piotra Jaroszewicza w maju 1976 r. $^{51}$. W polskich materiałach, przygotowujących wizytę prywatną Valerego Giscarda d'Estainga w Polsce (październik 1976 r.) pisze się natomiast o niedotrzymywaniu przez stronę francuską zobowiązania co do zorganizowania dwustronnego spotkania ekspertów w sprawie Biblioteki ${ }^{52}$.

Kolejne propozycje rozwiązania tego spornego problemu zarysowały się w trakcie rozmów, przeprowadzonych przez ambasadora PRL w Paryżu, Tadeusza Olechowskiego $z$ A. Poniatowskim w 1977 r. Wedle szyfrogramu, jaki dotarł do Warszawy 1 lipca tego roku, ówczesny przewodniczący THL miał wyrazić opinię, iż cenne księgozbiory Biblioteki Polskiej w Paryżu a zwłaszcza archiwalia stanowią bezdyskusyjnie skarb kultury polskiej i powinny służyć Polsce i Polakom zarówno w kraju ja na emigracji. Od wielu lat Polacy $z$ kraju odwiedzali Bibliotekę i korzystali $z$ niej bez najmniejszych ograniczeń. Poważny problem tej placówki to brak środków finansowych na remonty budynku i pomieszczeń oraz zabezpieczenie przechowywanych materiałów. Jako przewodniczący THL Poniatowski od wielu lat kontaktował się ze środowiskami polonijnymi w USA w celu zdobycia funduszy. Jak twierdził otrzymał wiele propozycji, które odrzucił, bo warunkowały pomoc finansową Amerykanów ich udziałem w zarządzaniu Biblioteką. Konkretnym osiągnięciem była pomoc Johnsonów, która zakładała utrzymanie dotychczasowego charakteru Biblioteki, wykluczając jakąkolwiek gestię władz francuskich, czy polskich. Ze względu na swój wiek (78 lat), Poniatowski rozważał sprawę sukcesji na jednego ze swych bratanków (m.in. syna Michela Poniatowskiego). Chciałby do tego czasu doprowadzić do uregulowania sytuacji prawnej Biblioteki, która decyzją władz francuskich sprzed trzech lat została ponownie powierzona w gestię (dzierżawę) THL na dalsze 18 lat. W tej sytuacji widziałby możliwość co prawda pozostawienia Biblioteki w gestii THL, ale również stworzenia organu nadzorczego w postaci komisji naukowej, do której weszliby również przedstawiciele nauki i kultury polskiej $z$ kraju. Koncepcję te według niego popierał M. Poniatowski ${ }^{53}$.

Sytuacji nie wyjaśniły jednak nawet kolejne rozmowy tego ostatniego w Warszawie 22 stycznia 1978 r. Sprawa powróciła w trakcie jego rozmowy z ministrem spraw zagranicznych Emilem Wojtaszkiem. Zastanawiano się m.in. nad tym, kto winien pokierować Biblioteką po „disparition” A. Poniatowskiego. Padały nazwiska Huberta d'Ornano i Philipe'a Poniatowskiego, ale żadna decyzja nie została podjęta ${ }^{54}$.

${ }^{51}$ AMAE, Europe 1971-juin 1976, 3487, Note de synthese, a.s. Voyage du Chef du Gouvernement polonais en France, 5-8 mai 1976.

${ }^{52}$ Archiwum Akt Nowych (dalej: AAN), Komitet Centralny Polskiej Zjednoczonej Partii Robotniczej (dalej: KC PZPR), XIA/747, Polsko-francuskie stosunki polityczne (materiały informacyjne w związku $Z$ wizytą prywatną w Polsce Prezydenta Republiki Francuskiej Valery Giscard d'Estaing w dniach 15-17 października 1976).

${ }^{53}$ AAN, KC PZPR, W. Zagraniczny sygn. tymcz. 850/24, Szyfrogram nr 415/III z Paryża, 1 lipca 1977.

${ }^{54}$ Archives Nationales 5 AG 3/AE 119, Note pour le President. Michel Poniatowski. Objet: Voyage a Varsovie le 22 janvier 1978. 
Do końca analizowanego okresu nie przezwyciężono impasu w omawianej kwestii. Dyskusje wokół Biblioteki Polskiej w Paryżu, jakie toczyły się w latach 1945-1970, znakomicie pokazują, jak losy tej zasłużonej dla kultury instytucji zostały uwikłane w międzynarodowy spór polityczny, którego stronami były: Warszawa, Paryż i środowiska polskiej emigracji we Francji. Sprzeczności interesów, wzajemne uprzedzenia i zmieniające się klimaty w stosunkach międzynarodowych sprawiały, że nie udało się znaleźć formuły kompromisu. Biblioteka stawała się elementem przetargu, ze szkodą dla realizacji jej podstawowej funkcji. 